\title{
ASSESSMENT OF TOXIC MATERIALS IN SUNAF MARSH (ALKHAWISA VILLAGE).
}

\author{
Mohammed D. Selman \\ Thi-Qar University - Marshes Research Centre
}

\begin{abstract}
This paper presents studying the pollution of water in Al-Sunaf marsh (Alkhawisa village) by evaluating its water quality which has physical and chemical properties and comparing them with the world health organization standards (WHO1993). Results show that the pollutants (TSS, Salinity, $\mathrm{Cl}^{-}, \mathrm{K}^{+}, \mathrm{Na}^{+}, \mathrm{Co}, \mathrm{Cu}, \mathrm{Zn}, \mathrm{PO}_{4}{ }^{-2}$ ) are not exceeding its guide levels. Also results show chronic effects of some chemical and physical properties, These Chronic effects result from the increasing of monthly concentrations for (Turbidity, Calcium, Chromium, Lead, Magnesium, Cadmium, Barium, Iron, Sulfate, chloride, Nickel and TDS) from its guide level which produce health and hazard effects on peoples who live in the boundaries of Sunaf marsh (Alkhawisa village), Results prevent the ability to use this water for different purposes.
\end{abstract}

key words: marshes, water quality, toxicity, drinking water.

$$
\begin{aligned}
& \text { الخلاصة } \\
& \text { هذا البحث يمثل دراسة التلوث في مياه هور السناف (قرية الخويسة) وذلك بتقييم نوعية المياه بما يملكه من خصائص }
\end{aligned}
$$

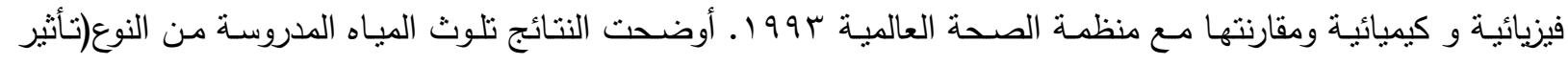

$$
\begin{aligned}
& \text { مزمن) لبعض الخصائص الفيزيائية والكيميائية. اوضحت النتائج ان الملوثات (المواد العالقة، الملوحة، ايون الصوديوم ، ايون } \\
& \text { البوتاسيوم، الكوبلت، النحاس، الزنك، الفوسفات) لم تتجاوز الحد المسموح بها. كذلك اوضحت النتائج هنالك تاثير مزمن } \\
& \text { لبعض الخصائص الفيزيائية والكيميائية وهذا ناتج من زيادة تركيز تلك الخصائص شهرياً وهي (الكدرة، الكروم، الرصاص، } \\
& \text { المغنيسيوم، الكادميوم، الباريوم، الكبريتات، الكلورايد والنيكل) حيث تتتج تأثثرات صحية وخطرة على الناس الذين يعيشون } \\
& \text { على حدود هذا الهور، كذلك أوصلت النتائج إلى حقيقة انه لايمكن استخدام المياه في هور السناف كمصدر مياه متعدد } \\
& \text { الاغراض. }
\end{aligned}
$$




\section{Introduction:}

Iraqi marshes are one of the most ancient marshes in the world and pride them selves on its beautiful scenery and its rich natural ecological system. Closely involved in the lives of people over many years, marshes have been an important water resource and helped create and preserve distinctive culture. The study area (N30 47.169, E46 33.688) (Sunaf Marsh) is apart of the south marshes as shown in Figure (1), it lies at the south eastern of Nassiriya city, also it is one of the largest marsh in Iraq with an area (515
$\mathrm{Km}^{2}$, it holds approximately $\left(334 \mathrm{~m}^{3} / \mathrm{sec}\right)$ for every $1 \mathrm{~m}$ depth, the source of its water that flow in it is Euphrates river.Pollutants enter marshes as a result of natural physical and chemical processes such as weathering and leaching. Some chemical elements found in the water are highly affective upon human health, such as copper, iron, magnesium, sodium, zinc and other are all necessary for human life functions. If some of these elements are ingested in excessive amounts, toxicity or death can result ${ }^{(1)}$.

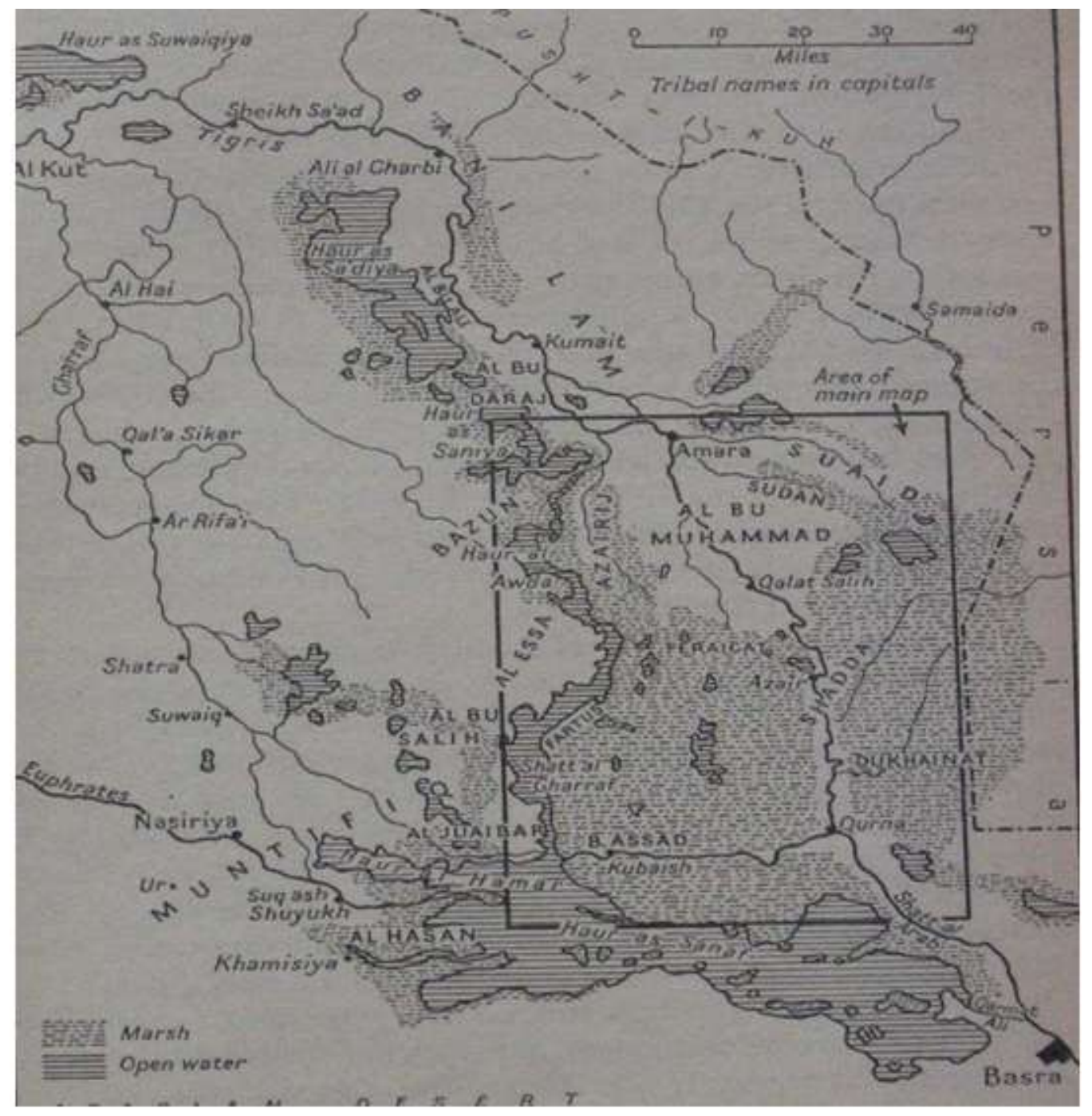

Figure (1) Al Sunaf Marsh Water Map. 
Because of the solvent properties of marsh water many substances may be found in it and some of them are potentially hazardous to human life. In relation to chemically effects it is important to appreciate that these accure in two types: acute effects where the consequence of consumption of the contaminate water are more or less immediately apparent, and chronic effects where continued ingestion of the contaminate water produce along term $\operatorname{hazard}^{(2)}$.

The main source of water pollution (especially heavy metals that caused high toxicity for human) in Sunaf marsh is as follows:

- Domestic waste water is the largest single source of heavy metals discharged to the marsh environment en effluents or sewage sludge which generally contain high elevated levels of copper, lead, zinc, chromium, etc..

- Euphrates River plays a major role in the transport of pollutants such as heavy metals in solution or in association with suspension solids.

- Agricultural effluent from farmland, such as paddy fields and farms in addition to fertilizer.

- Leaching processes that occur between water body in marsh and its soil resulting in transport of heavy metals and other pollutants(3).

The effect of toxic contaminants (metals, organic compounds, microorganisms) on human health can be classified as either acute or chronic. The reaction to a substance causing serious illness or death in an individual within 48 hours after exposure is considered acute toxicity. On the other hand chronic toxicity is a longer term effect on health due to frequent exposure to small amounts of a toxic substance. Chronic reactions to chemicals are difficult to study and our knowledge of the chronic toxic effects of nearly all chemicals is very poor. Examples of chronic health effects would be kidney and liver disease, cancer, mental illness, etc ${ }^{(4)}$.

Drinking water is regulated by guidelines which establish the maximum contamination levels. Most of these levels allow a sufficient margin of safety; however, one must remember that acceptable contaminant levels vary widely among individuals and population groups ${ }^{(5)}$.

\section{Data Analysis:-}

Samples take from the regions that nearest to the village (its location by GPS (N30 47.169, E46 33.688). Table (1) shows the monthly readings for the chemical and physical parameters for Al-Sunaf marsh water for 5 months (July, August, September, October, November for year 2005).Titration processes used for calcium and magnesium ions, total suspension solids and chloride ion analysis according to (APHA 1999). Toal dissolved solid meter used to calculate TDS,UVspectrophotometer used for phosphate ion measurement with wavelength $(680 \mathrm{~nm})$, sulfate ion measurement is done by Spectrophotometer with wave length (420 $\mathrm{nm}$ ). Atomic Absorption devise used to measure the heavy metals in addition to potassium and sodium ions. All these samples are done in laboratories of Baghdad University (Chemical science Department).

\section{Results and Discussion:-}

Figure (3) shows monthy values of Total Suspension Solids (TSS) which reachs maximum value of $100 \mathrm{ppm}$, these values in the range of the guide value according to WHO standards. Salinity values changes 
with months as shown in fig.(4) which appears amaximum value at $6.01 \mathrm{SAR}$. Table (1) shows chronic effect from high exposure time of some chemical and physical properties that produce toxic effects on health population. Chronic effect of these properties resulting from increasing of monthly reading for these concentrations. Also water is polluted with other parameters which increase this effect adverse health consequences may arise from exposure to chemicals following long-term and, in some cases, short-term exposure. Furthermore, concentrations of most chemicals in drinking-water do not normally .actuate widely over short periods of time. Management through periodic analysis of drinking-water quality and comparison with WHO standards for drinking such as guideline values is therefore commonly applied to many chemicals in drinking-water where chronic effects arise from long-term exposure. The chemical and physical properties that produce these effects.

Turbidity values of these studied samples are very high during months as shown in figure (2), these high values resulting from colloidal soil, clay, discharge of domestic uses and animal movement. Also these high concentrations can serve as a medium for many toxic chemical such as heavy metals and pesticides are selectively absorbed on suspend matter. The concentration of calcium and magnesium are high as shown in fig.(5) and fig.(6) respectivity, these high values because of the main source for the marsh (Euphrate river) pass zone contain limestone. Any excess amounts are quickly expelled by the body. It can, however, create a problem for people with kidney disease. They may develop toxic reactions to high levels of magnesium, including muscle weakness, coma, hypertension, and confusion (6). $\mathrm{CaCO} 3$ concentrations not exceed the guid level greatly as shown in fig.(7). Figure (8) shows chloride concentrations exceed the guide level for health. High concentrations of chloride give a salty taste to water and beverages. Taste thresh-olds for the chloride anion depend on the associated cation and are in the range of $200-300 \mathrm{mg} / \mathrm{litter}$ for sodium, potassium and calcium chloride. Concentrations in excess of $250 \mathrm{mg} /$ liter are increasingly likely to be detected by taste, but some consumers may become accustomed to low levels of chlorideinduced taste. No health-based guideline value is proposed for chloride in drinkingwater. But it is danger in future when it treated.

Potassium and sodium ions monthly concentration shown in fig.(9) and fig.(10) receptivity, both ions not reach more than guide level. The presence of high concentration of $\mathrm{Ni}$ in water can cause Lung embolism Heart disorders, Asthma and chronic bronchitis as in figure (11). Manganese and cobalt monthly concentration in the water in acceptable limits in all months as shown in fig.(12) and fig. (13) for $\mathrm{Mn}$ and Co respectively. Mn and Co metals exit in the soil and sediment naturally.

Monthly concentrations of trace elements $(\mathrm{Cd}, \mathrm{Fe}, \mathrm{Pb}, \mathrm{Cu}, \mathrm{Cr}, \mathrm{Zn})$ shown in figures $(14,15,16,17,18,19)$ respectively, but with deviation from guide level (98.89\%, 4.45\%, 89.58\%, 56.9\%) for $\mathrm{Cd}$, $\mathrm{Fe}, \mathrm{Pb}$ and $\mathrm{Cr}$ respectively, copper and Zinc concentrations not exceed the guide level. These high concentrations due to the fact that waste water polluted the euphrate river and domestic waste from the people discharged without any treatment. It is associated with kidney disease and linked to hypertension. There is also some evidence that cadmium can cause mutations, these leads to allergic dermatitis, Alteration of 
genetic material, Lung cancer and Death. The health effects of barium depend upon the water-solubility of the compounds. Barium compounds that dissolve in water can be harmful to human health. The uptake of very large amounts of barium that are water-soluble may cause paralyses and in some cases evendeath.. Small amounts of water-soluble barium may cause a person to experience breathing difficulties, increased blood pressures, stomach irritation, muscle weakness, changes in nerve reflexes, swelling of brains and liver, kidney and heart damage, therefore, figure (20) shows this effect from high concentrations during
months(8).The presence of sulphate in water in high concentration as hown in fig. (21) due to the abundance of gypsum in the south region of iraq. It deviates from guide level by $(69 \%)$ which cause laxative effects in unaccustomed consumers. Fig.(22) shows the value of TDS in marsh ,the range of TDS in sunaf marsh between $(1510-1940 \mathrm{mg}$ /1)these values main that the Sunaf marsh in Brackish water class, . The high values of TDS in some marshes due to the high temperature increasing evaporation in these marshes remaining high concentration of salts.

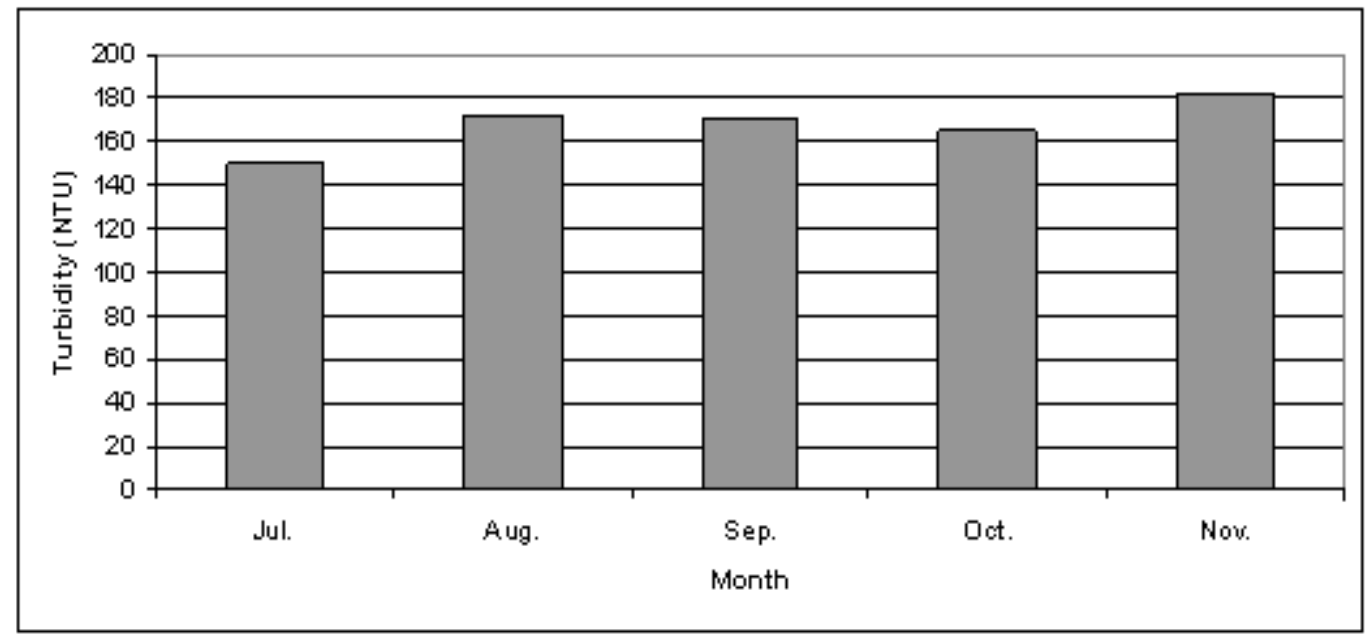

Fig. 2 Turbidity Values in (July, August, September, October, November 2005)

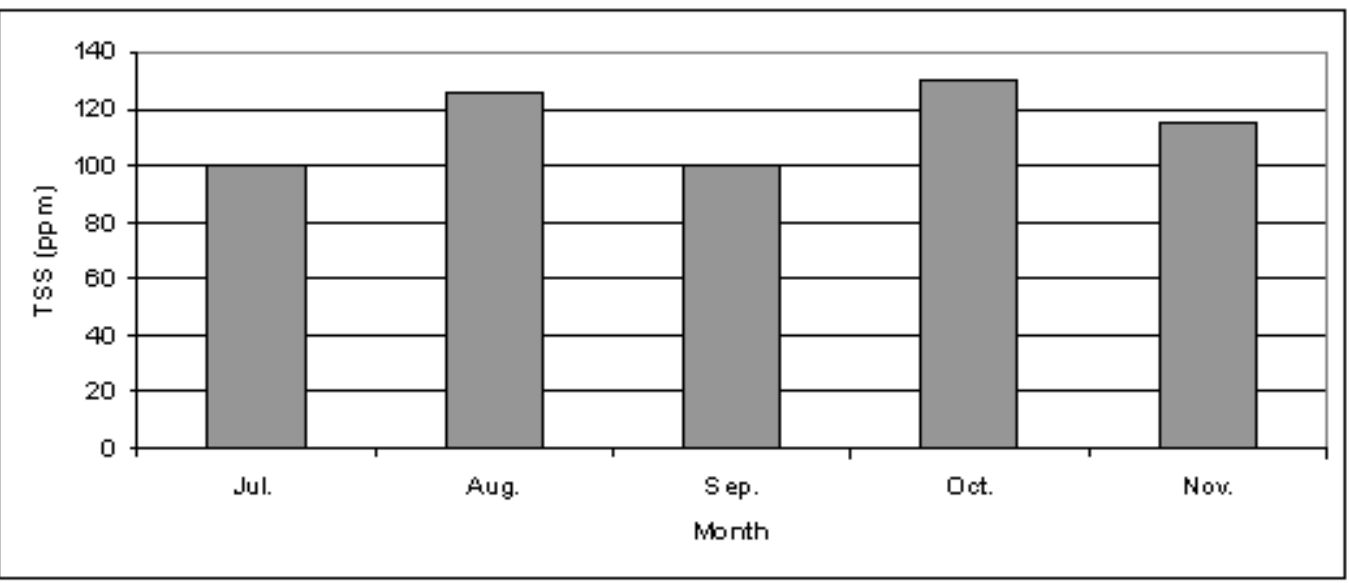

Fig.3 TSS Concentrations in (July, August, September, October, November 2005) 


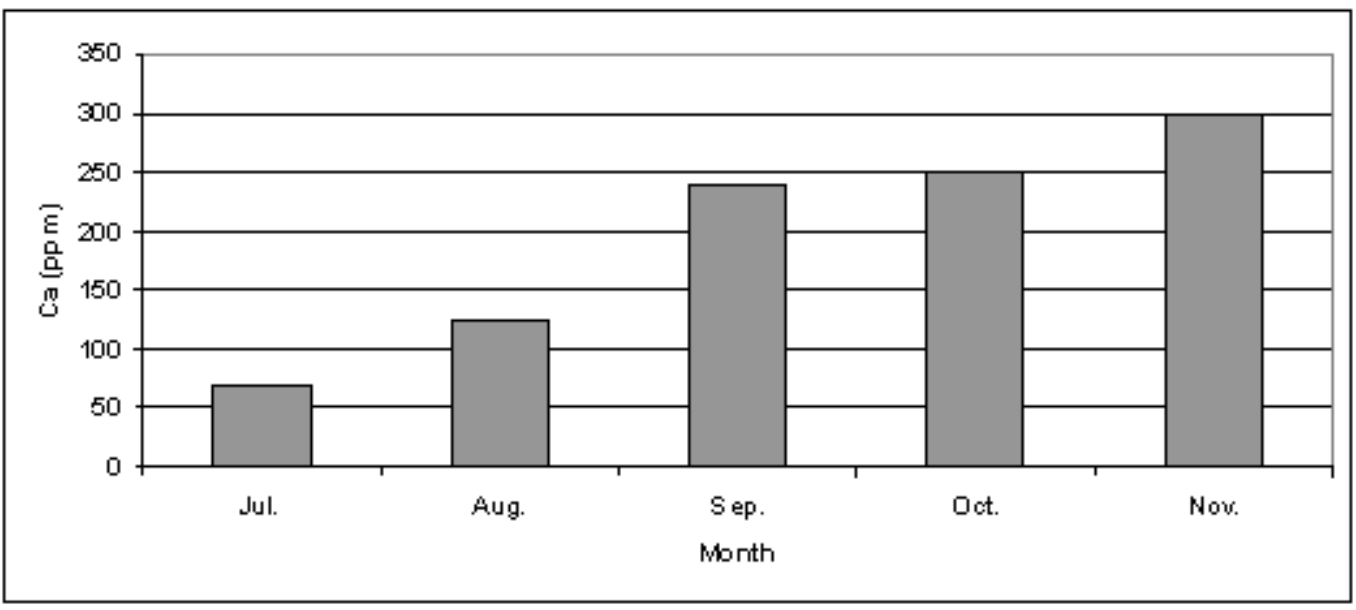

Fig.4 Calcium Concentrations in (July, August, September, October, November 2005)

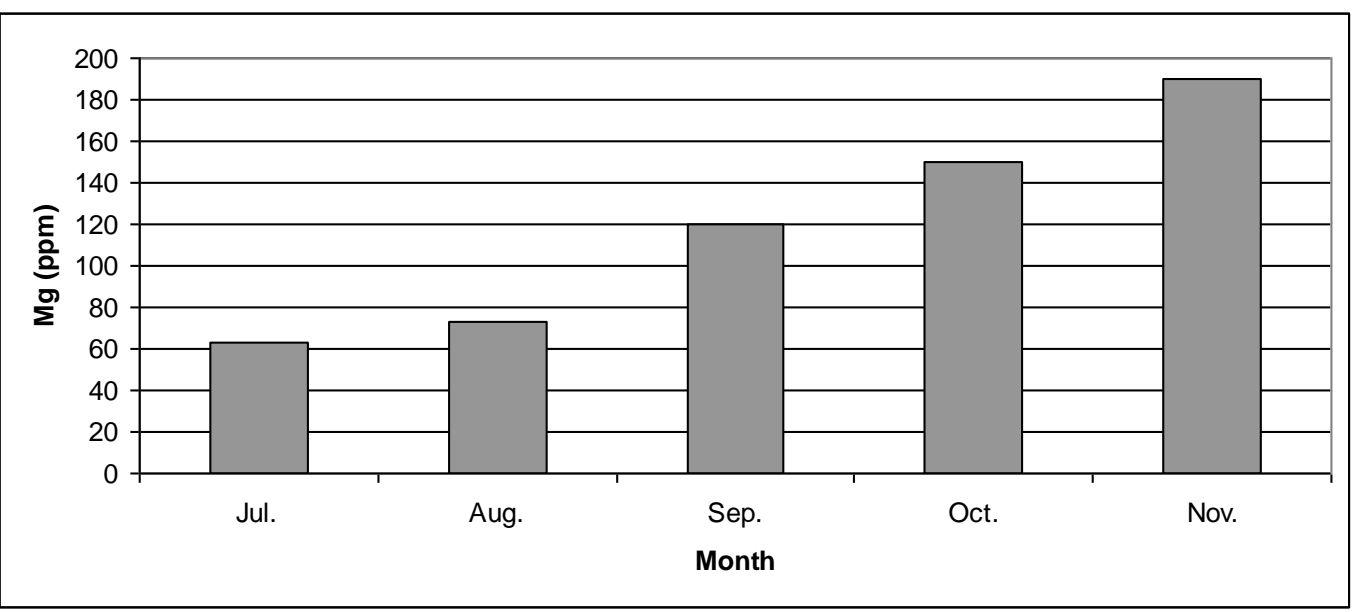

Fig.5 Magnesium Concentrations in (July, August, September, October, November 2005)

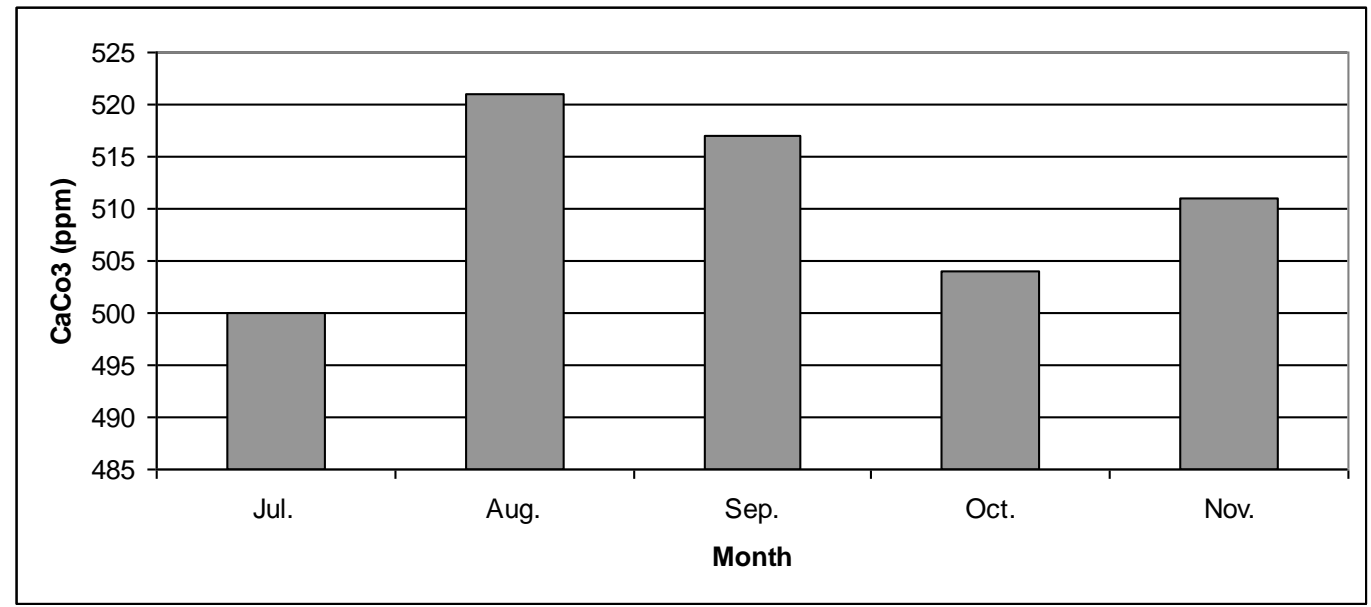

Fig.6 CaCo3 Concentrations in (July, August, September, October, November 2005) 


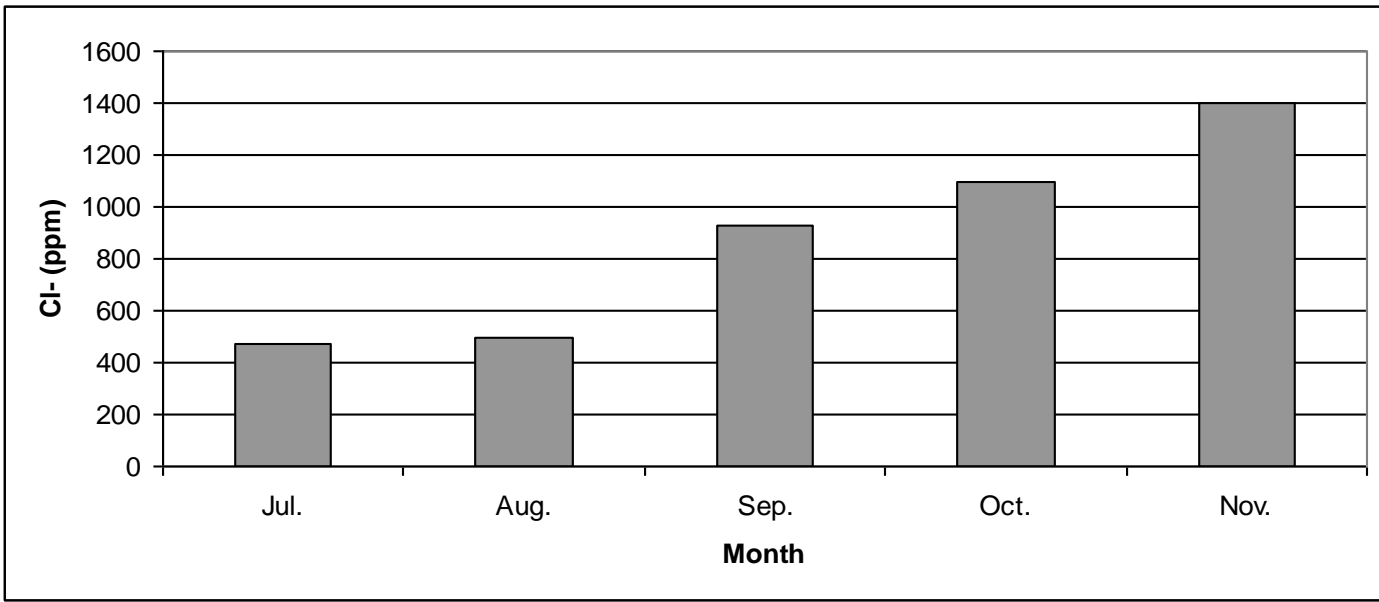

Fig.7 $\mathrm{Cl}^{-}$Concentrations in (July, August, September, October, November 2005)

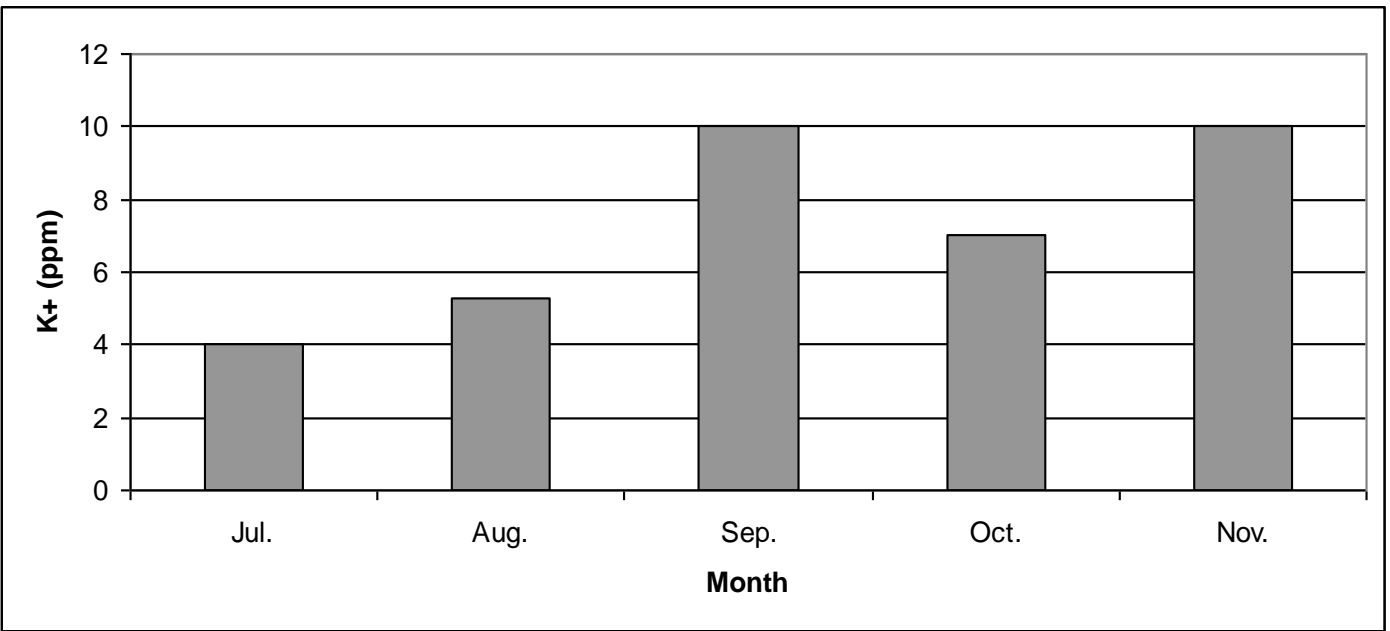

Fig.8 K+ Concentrations in (July, August, September, October, November 2005)

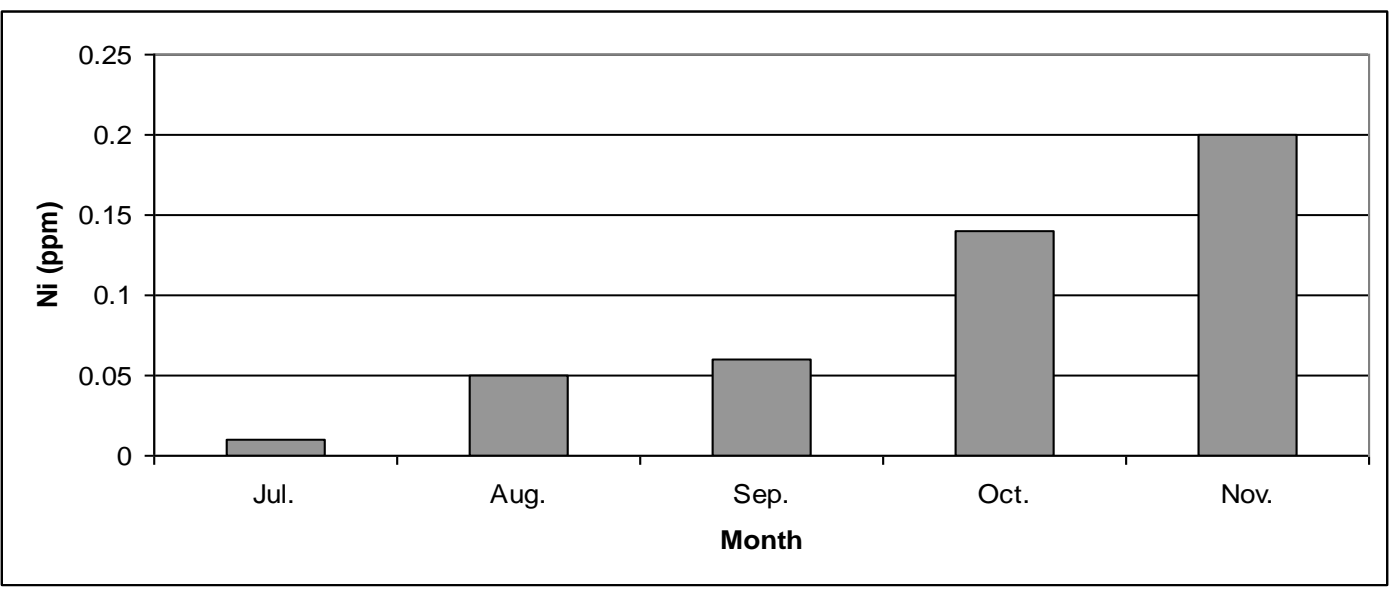

Fig.9 Ni Concentrations in (July, August, September, October, November 2005) 


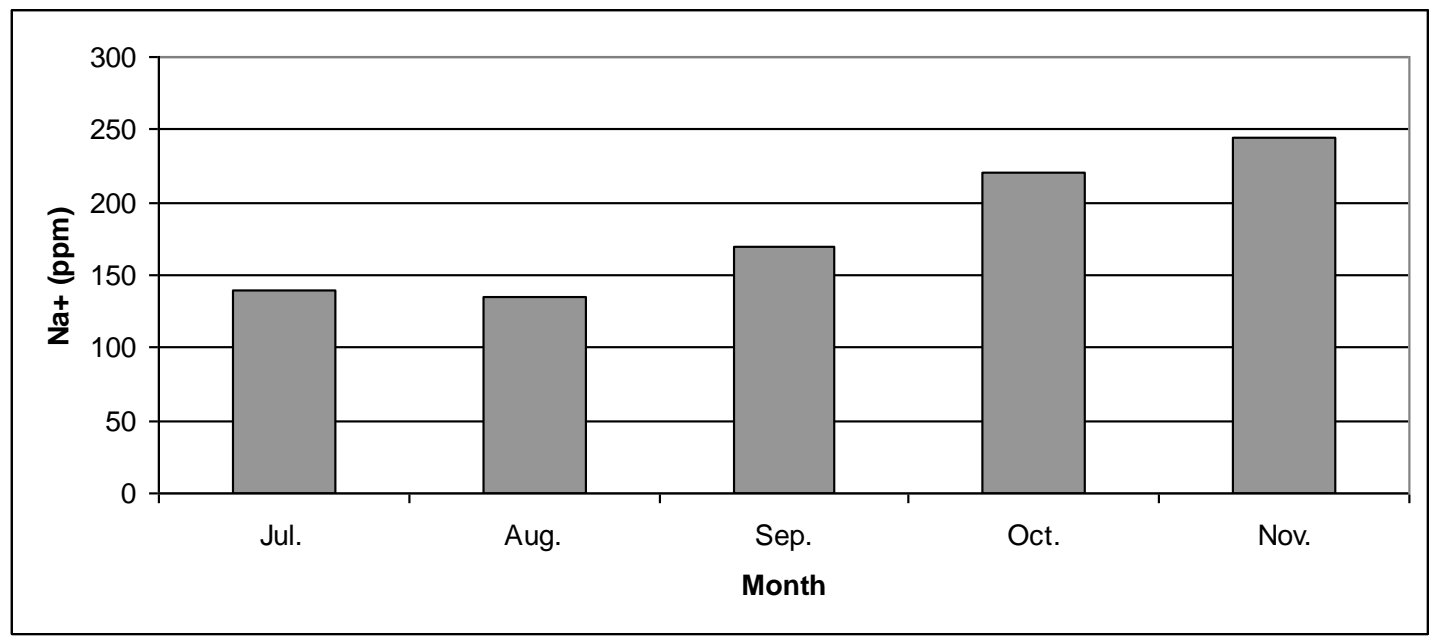

Fig.10 Na Concentrations in (July, August, September, October, November 2005)

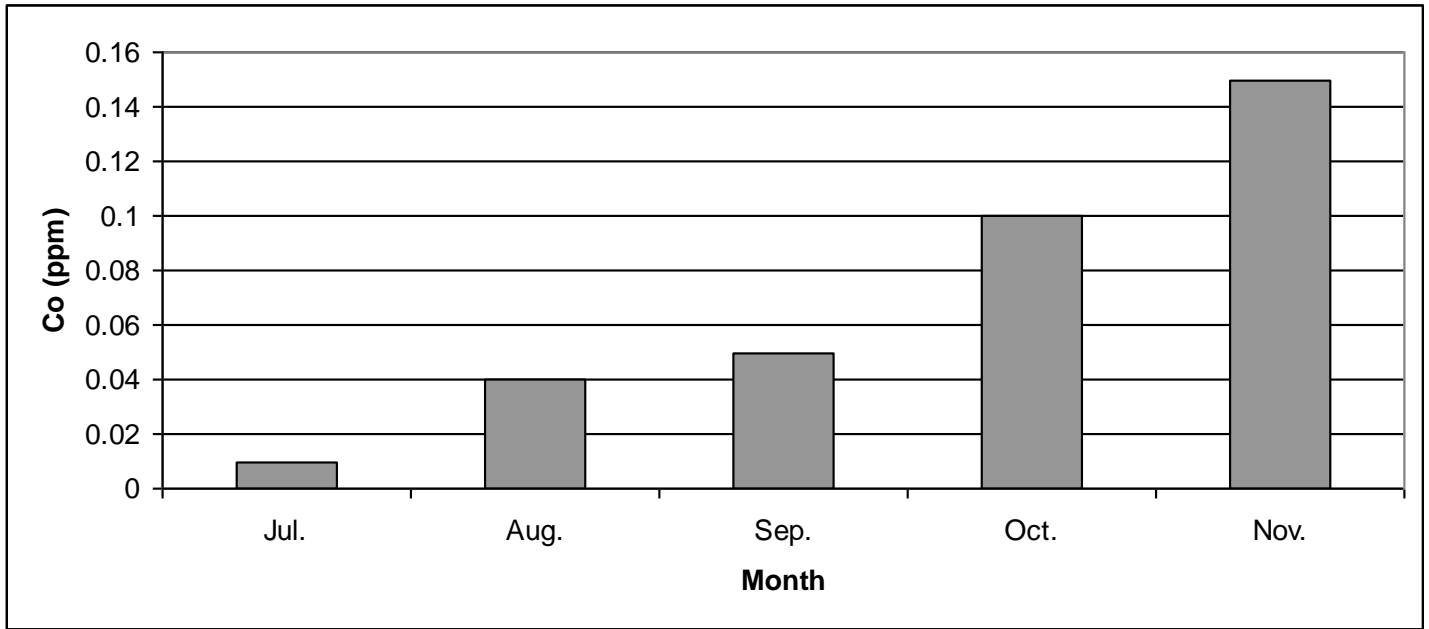

Fig.11 Co Concentrations in (July, August, September, October, November 2005)

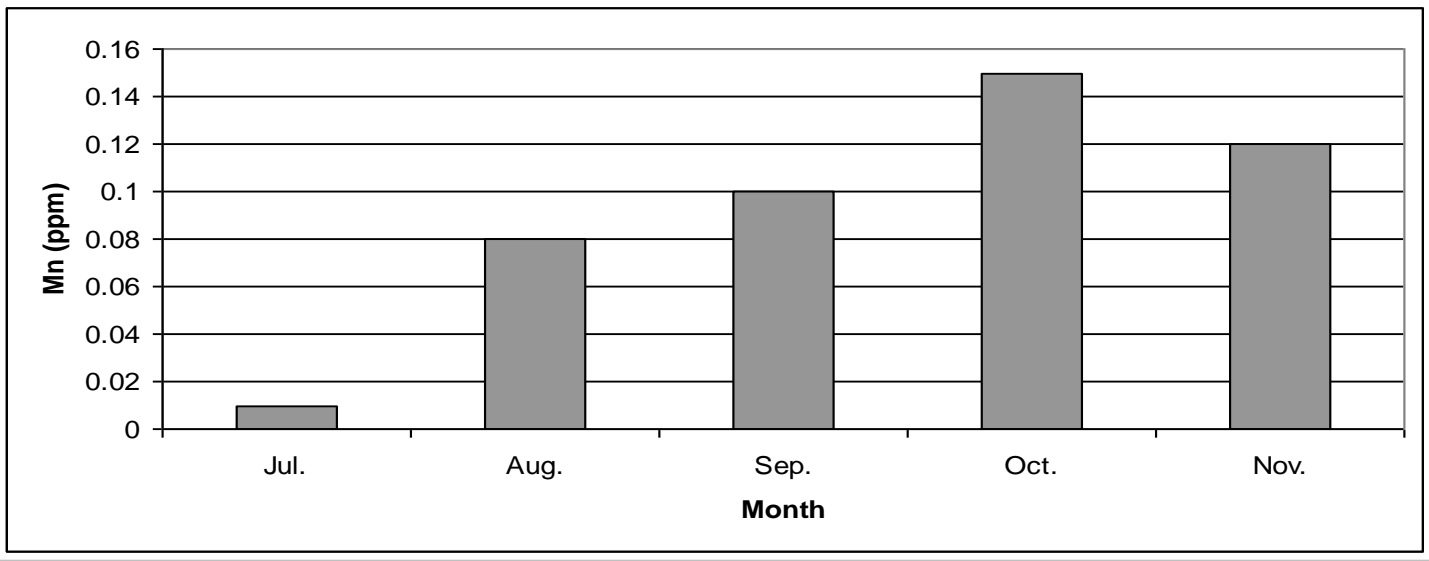

Fig.12 Mn V Concentrations in (July, August, September, October, November 2005) 


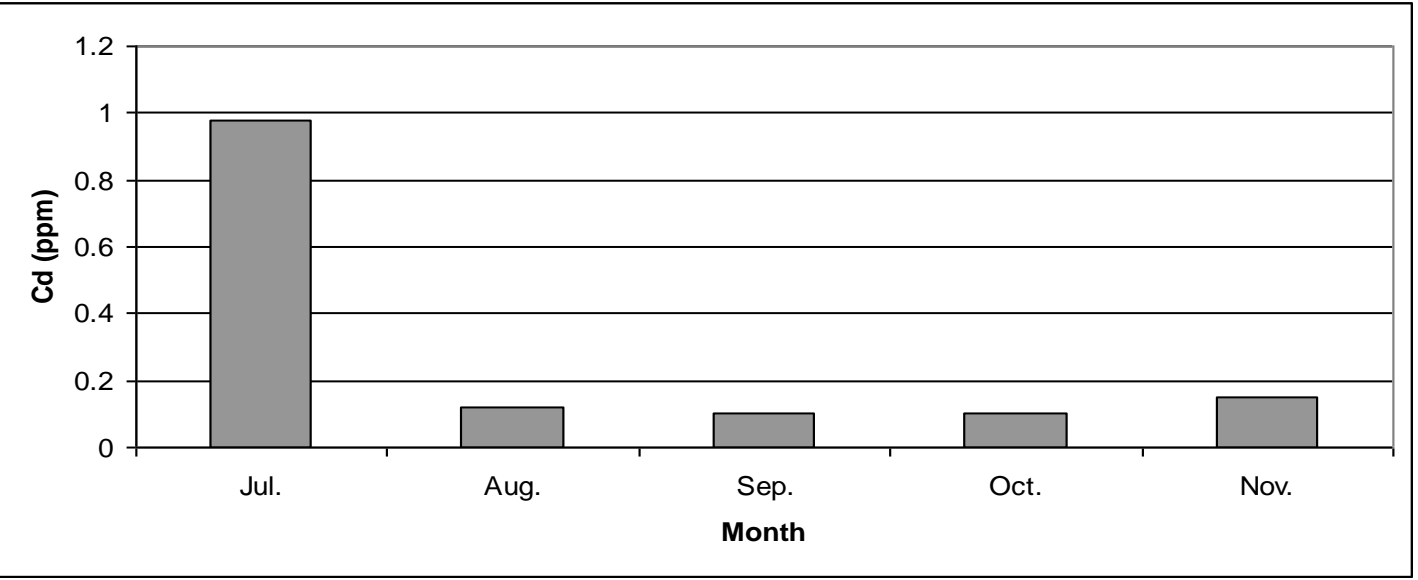

Fig.13 Cd Concentrations in (July, August, September, October, November 2005)

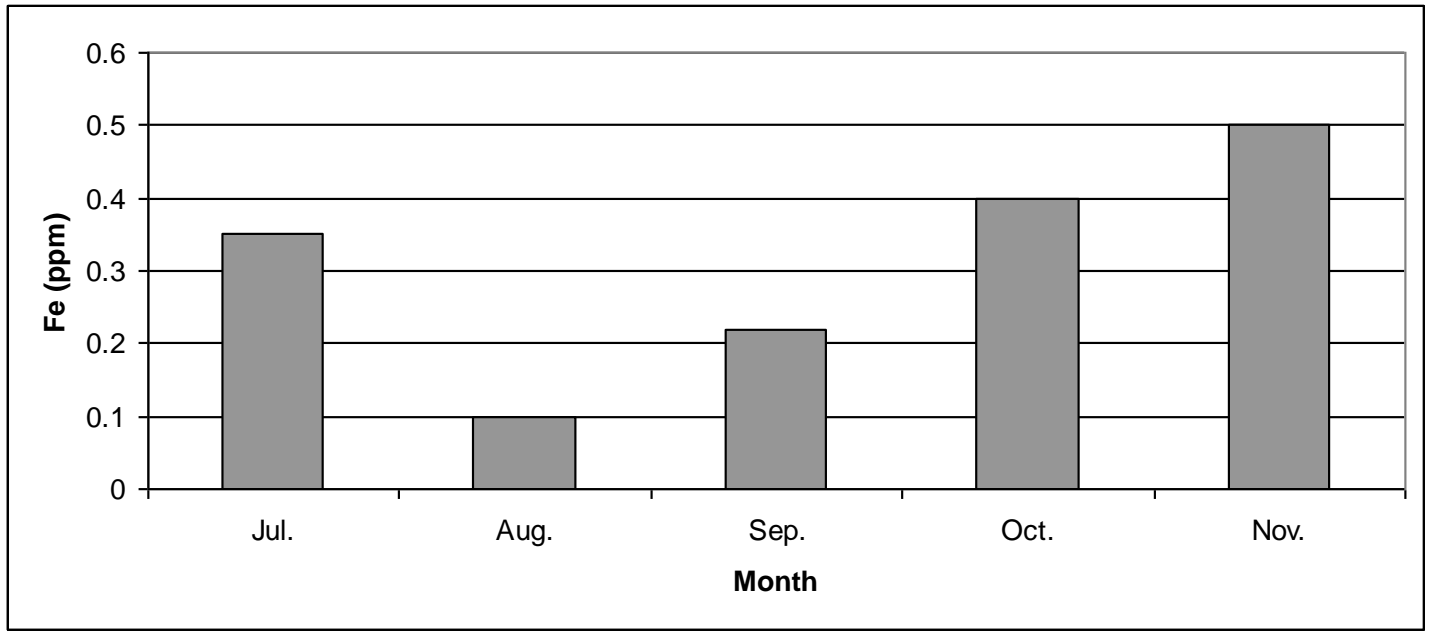

Fig.14 Fe Concentrations in (July, August, September, October, November 2005)

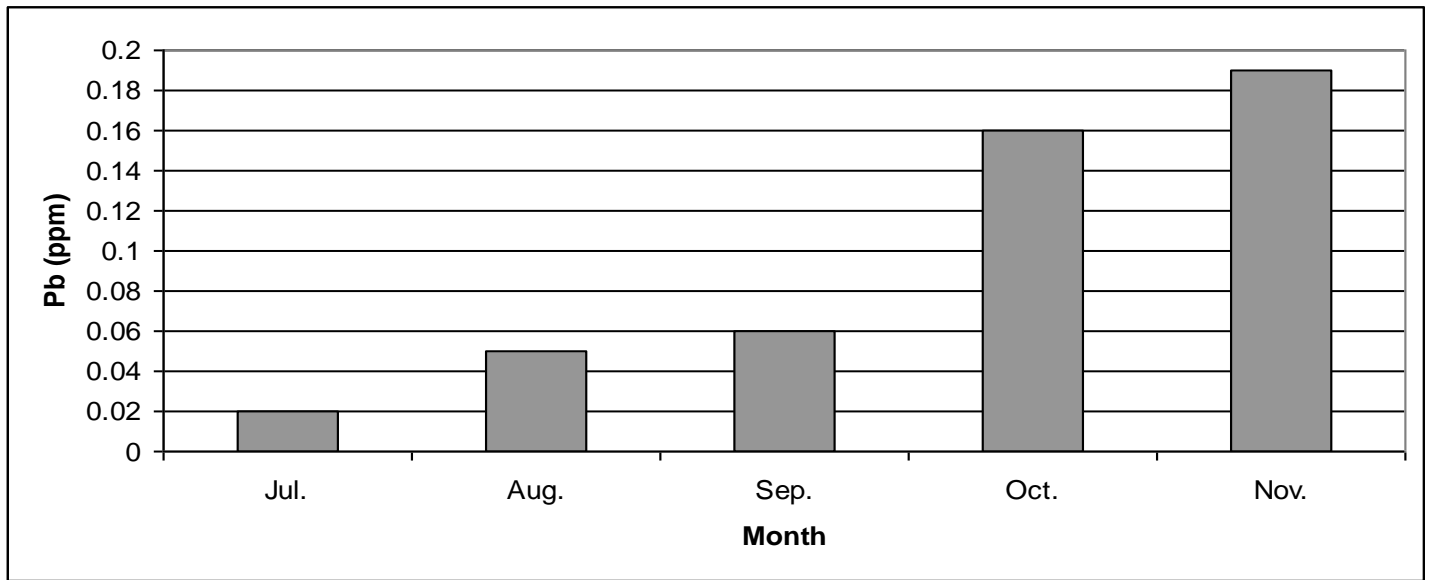

Fig.15 Pb Concentrations in (July, August, September, October, November 2005) 


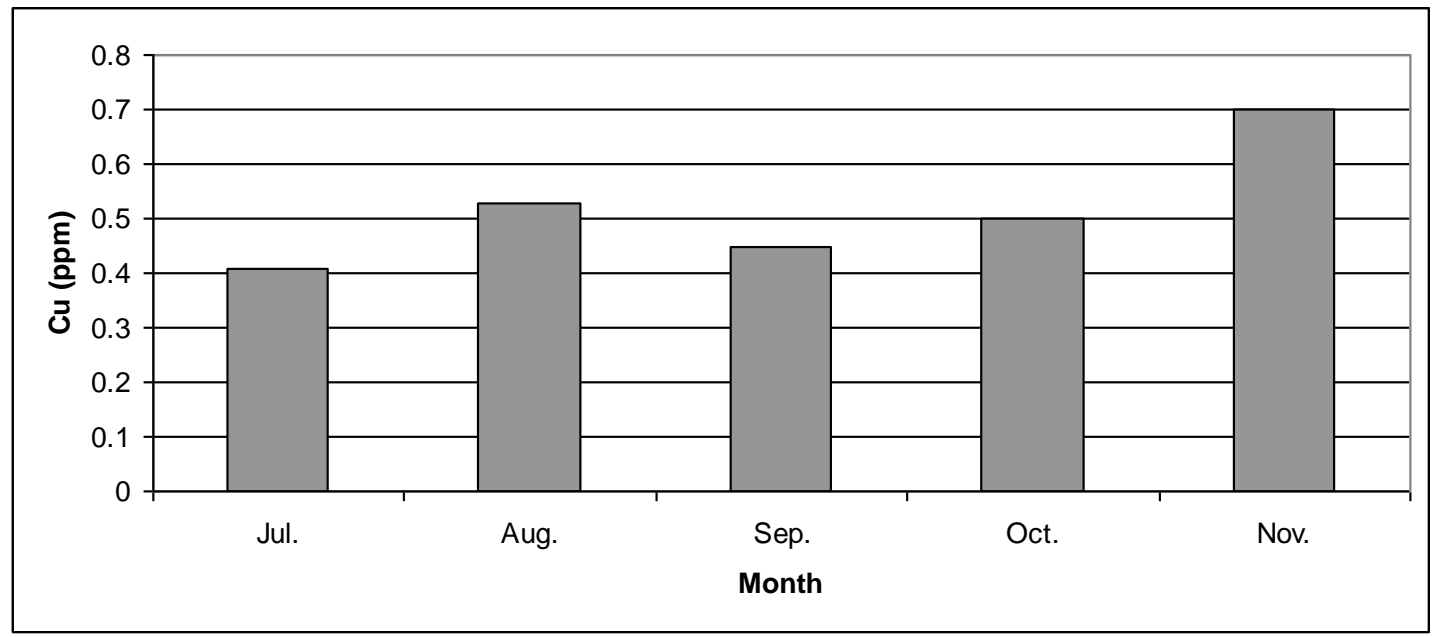

Fig.16 Cu Concentrations in (July, August, September, October, November 2005)

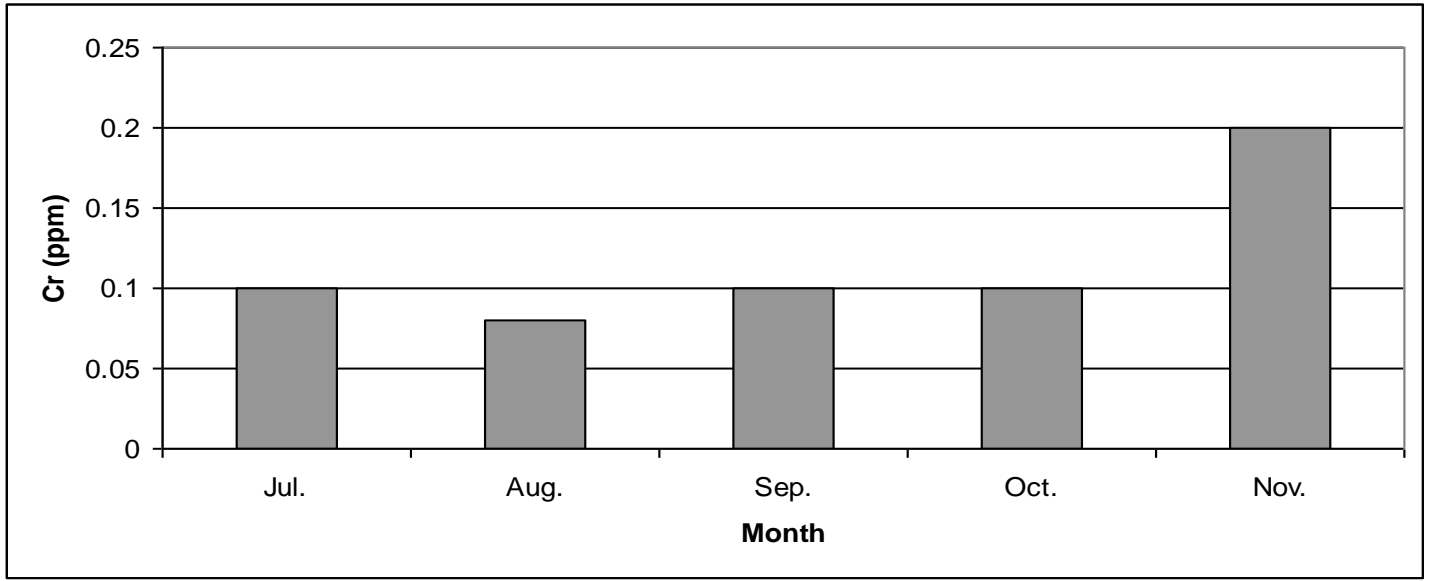

Fig.17 Cr Concentrations in (July, August, September, October, November 2005)

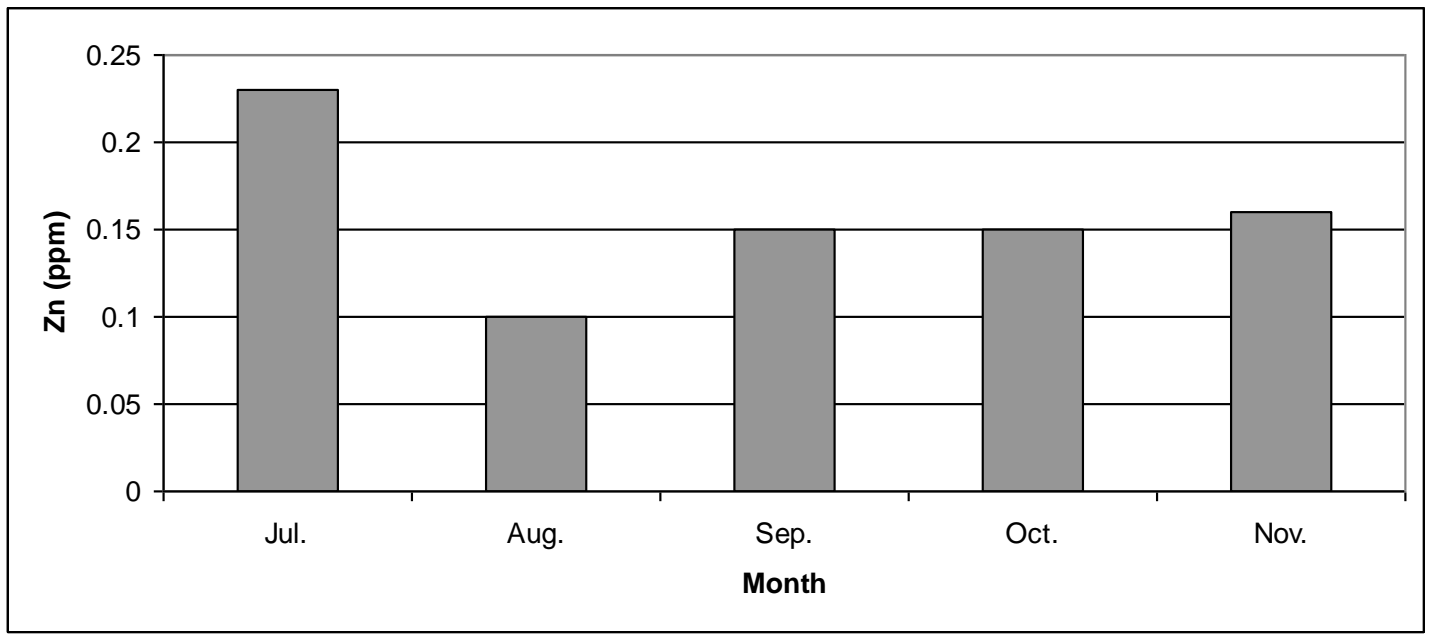

Fig.18 Zn Concentrations in (July, August, September, October, November 2005) 


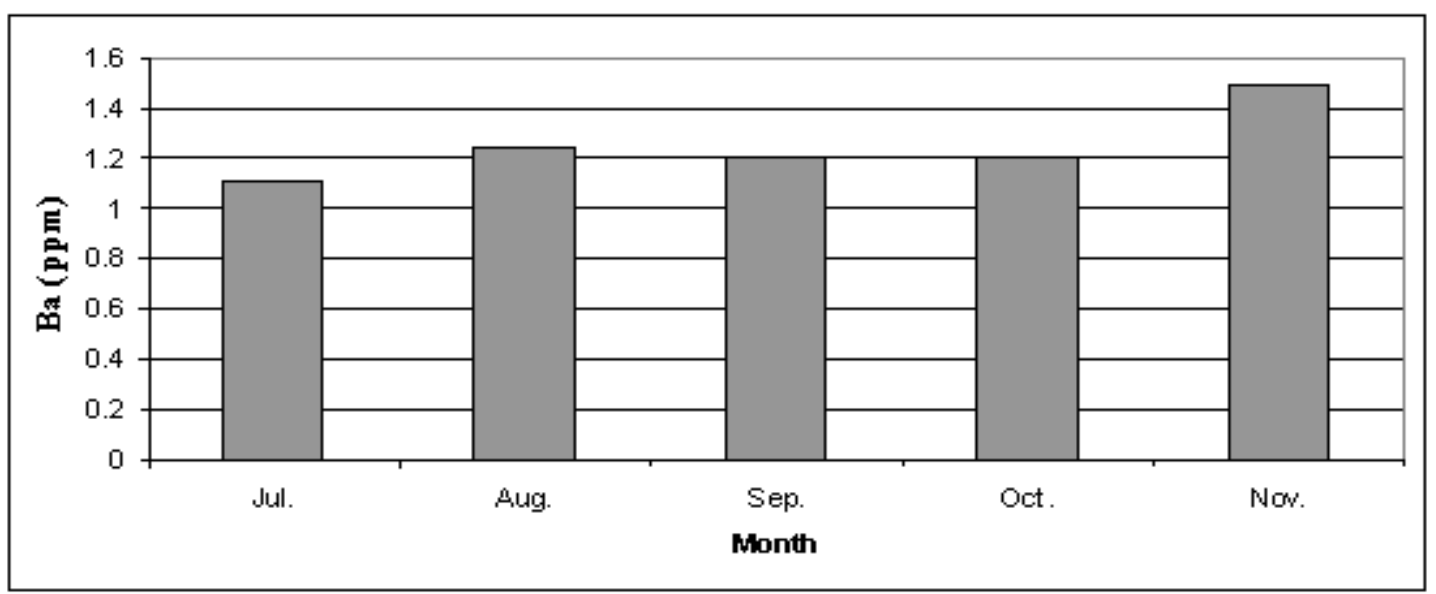

Fig.19 Ba Concentrations in (July, August, September, October, November 2005)

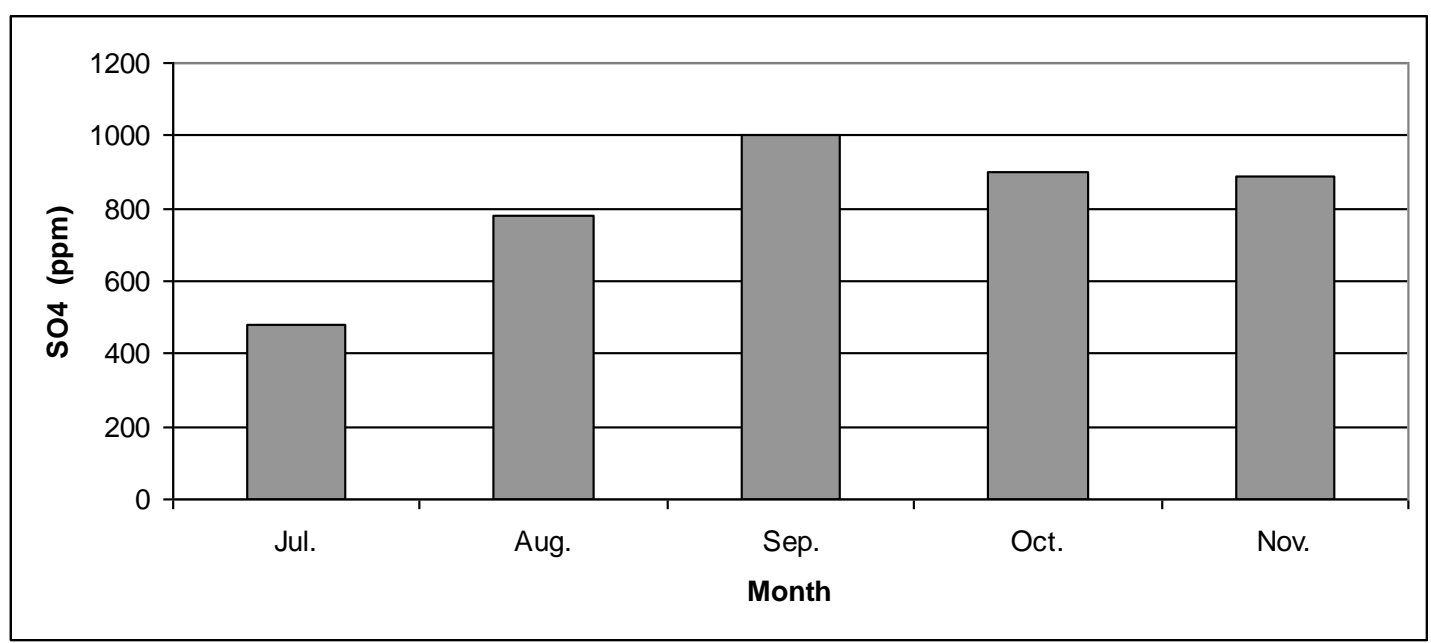

Fig.20 SO4 ${ }^{-2}$ Concentrations in (July, August, September, October, November 2005)

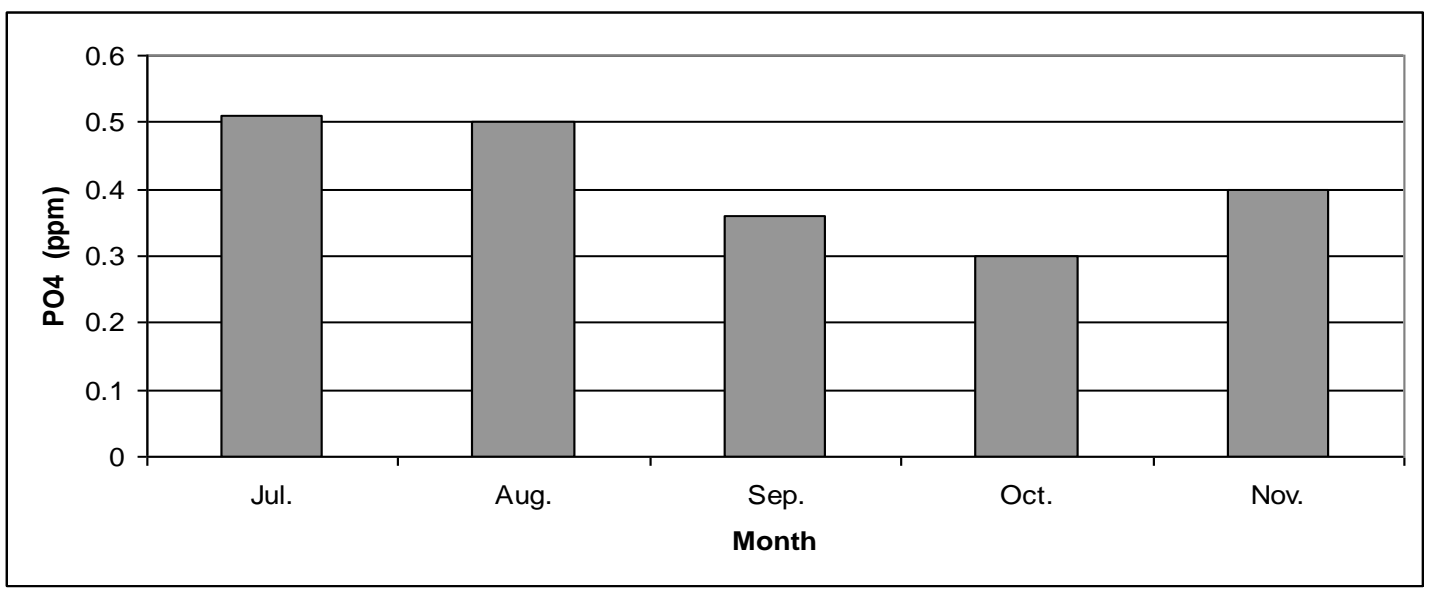

Fig.21 PO4 ${ }^{-2}$ Concentrations in (July, August, September, October, November 2005) 


\section{J.Thi-Qar Sci.}

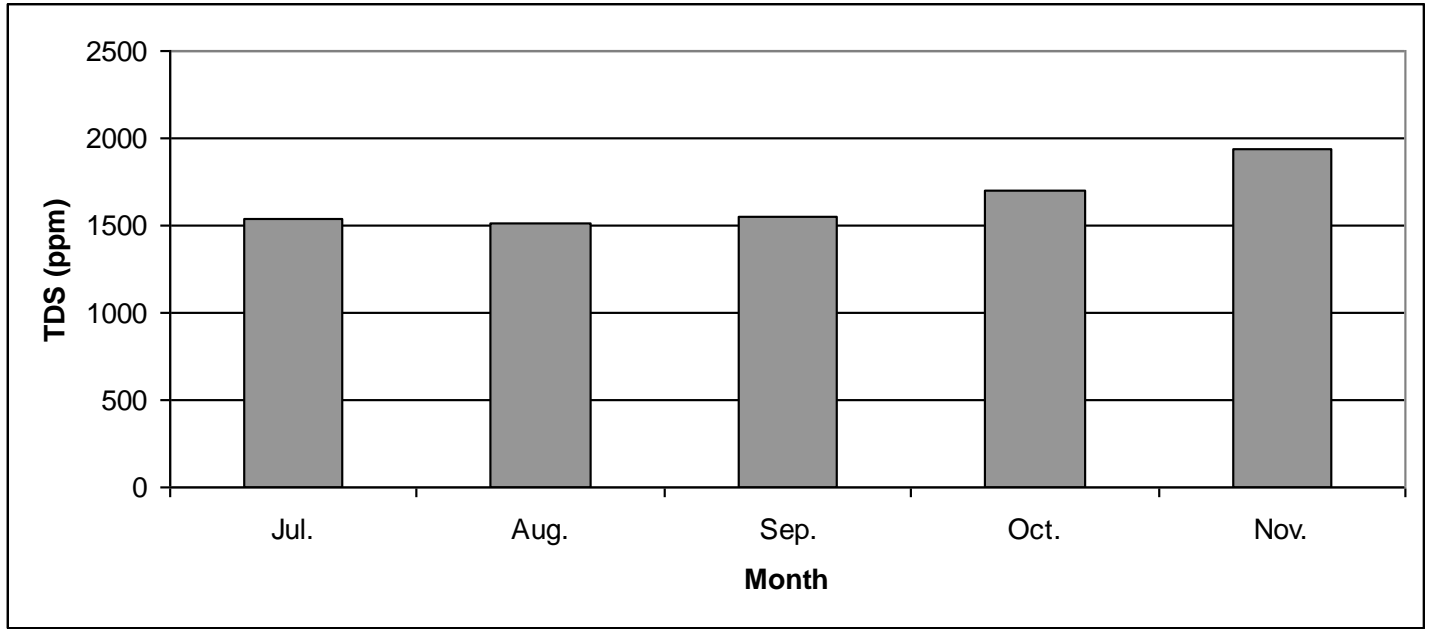

Fig.22 TDS Concentrations in (July, August, September, October, November 2005)

Table (1) Water Quality Data For Sunaf Marsh At (Alkhawisa Village)

\begin{tabular}{|c|c|c|c|c|c|c|c|}
\hline $\begin{array}{l}\text { CHARACTERIZATIOH } \\
\text { (GM/LUHLESS } \\
\text { SHOWH) }\end{array}$ & JULY & AUGUST & SEPTEMBER & OCTOBER & HOVEMBER & $\begin{array}{l}\text { GUIDE } \\
\text { LEVEL } \\
\text { (PPM) }\end{array}$ & $\begin{array}{l}\text { DEVIATIOH } \\
\text { PERCEHTAGE }\end{array}$ \\
\hline Turbidity(NTU) & 150 & 172 & 170 & 165 & 182 & 5 & $97 \%$ \\
\hline TSS & 100 & 125 & 100 & 130 & 115 & 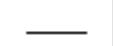 & 0 \\
\hline Salinity(SAR) & 4.4 & 5.02 & 6.01 & 5.59 & 6.00 & & 0 \\
\hline $\mathrm{Ca}^{-2}$ & 96.192 & 125 & 240 & 250 & 300 & 50 & $7524 \%$ \\
\hline $\mathrm{Mg}^{-2}$ & 6332 & 73 & 120 & 150 & 190 & 50 & $58 \%$ \\
\hline $\mathrm{CaCO}_{3}$ & 500 & 521 & 517 & 504 & 511 & 500 & $2 \%$ \\
\hline $\mathrm{Cl}^{-}$ & 476 & 500 & 925 & 1100 & 1400 & 250 & $7159 \%$ \\
\hline $\mathrm{K}^{*}$ & 4.0 & 5.3 & 100 & 7.0 & 10 & 12 & 0 \\
\hline $\mathrm{Ha}^{2}$ & 140 & 135 & 170 & 221 & 244 & 200 & 0 \\
\hline $\mathrm{Hi}$ & 0.01 & 0.05 & 0.06 & 0.14 & 0.2 & 0.02 & $7826 \%$ \\
\hline $\mathrm{Mn}$ & 0.01 & 0.08 & 0.1 & 0.15 & 0.12 & 0.5 & 0 \\
\hline Co & 0.01 & 0.04 & 0.05 & 0.1 & 0.15 & - & 0 \\
\hline $\mathrm{Cd}$ & 0.98 & 0.12 & 0.1 & 0.1 & 0.15 & 0.003 & $9889 \%$ \\
\hline $\mathrm{Fe}$ & 0.35 & 0.1 & 0.22 & 0.4 & 0.5 & 0.3 & $4.45 \%$ \\
\hline $\mathrm{Pb}$ & 0.02 & 0.05 & 0.06 & 0.16 & 0.19 & 0.01 & $8958 \%$ \\
\hline $\mathrm{Cu}$ & 0.41 & 0.53 & 0.45 & 0.5 & 0.7 & 1 & 0 \\
\hline $\mathrm{Cr}$ & 0.1 & 0.08 & 0.1 & 0.1 & 0.2 & 0.05 & $569 \%$ \\
\hline $\mathrm{Zn}_{\mathrm{n}}$ & 0.23 & 0.1 & 0.15 & 0.15 & 0.16 & 3 & 0 \\
\hline $\mathrm{B}$ & 1.11 & 1.24 & 1.21 & 1.2 & 1.5 & 0.3 & $76 \%$ \\
\hline $\mathrm{SO}_{4}$ & 480 & 780 & 1000 & 900 & 890 & 250 & $69.13 \%$ \\
\hline $\mathrm{PO}_{4}{ }^{2}$ & 0.51 & 0.5 & 0.36 & 0.3 & 0.4 & 2.2 & 0 \\
\hline TDS & 1540 & 1510 & 1556 & 1700 & 1940 & 1000 & $40 \%$ \\
\hline
\end{tabular}




\section{4- conclusion:-}

Sunaf marsh water (Alkhawisa village) is polluted with high concentrations of some chemical and physical parameters. These parameters indicate toxicity as chronic effect from high exposure time of people for water that may use it as a drinking water. The comparison of Sunaf water quality with world health organization results chronic

effect for (Turbidity, Chromium, Lead, Magnesium, Cadmium, Barium, Sulfate, chloride and Nickel,), these give deviation from guide levels as $(97 \%$, $65.9 \%, 89.58 \%, 58 \%, 9.89 \%, 76 \%, 69.13 \%$, $71.59 \%, 78.26 \%$ ), therefore water does endanger people life and does hinder the use of drinking.

\section{$\underline{\text { Recomondations:- }}$}

- Controlling the pollution sources in an euphrate river which results from wastewater.

- Installation of water treatment plant in this village.

- Studying the hydrology of sunaf marsh water in order to obtain an overview on it and know the main sources of pollution.

\section{Reference:-}

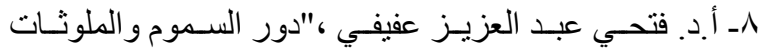

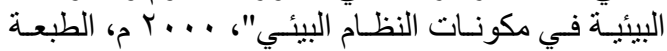

$$
\begin{aligned}
& \text { الاولى، دار الفجر للنشر والتوزيع. } \\
& 9 \text { ـ د. سعيد محمد الحفار، } 991 \text { 19 ، "الموسو عة البيئية العربية"، البية، }
\end{aligned}
$$

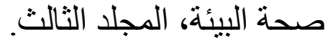

Environment of Lake Biwa and the Yado River Basin.

2-Alloway B.J. and Ayres D.C., 1997, "Chemical Principles Of Environmental Pollution ", 2nd edition, Chapman and hall

3- Jeffery pierce J., Ruth W. and Aarne P., 1998' Environmental Pollution And Control", 4th edition, Butterworth-Heinemann.

4-Saburo M., Barret B. and Banerjee J., 1991"Toxic Substances Management In Lakes And Reservoirs", guidelines of lake management, volume 4 .

5-WHO, "Guidelines For Drinking Water Quality", 2nd edition, Vol.1 and2, Geneva,1993. Internate conection, WWW.who.int/water-sanitationhealth/dwg/gdw93/en.

6-Effect of heavy metals on health, internate connection,2005, web site,. http://www.lenntech.com/periodicchart.htm.

7-APHA, 1999 "Standards Method for the Examination at Water and Waste Water", American Puplic Health Association. 